University of Nebraska - Lincoln

DigitalCommons@University of Nebraska - Lincoln

Nebraska Game and Parks Commission -- Staff

Research Publications

Nebraska Game and Parks Commission

September 1969

\title{
Beggar-Tick Injury to a Northern Cricket Frog and Two Species of Minnows
}

Larry A. Witt

Nebraska Game and Parks Commission

Leonard $\mathrm{H}$. Sisson

Nebraska Game and Parks Commission

Follow this and additional works at: https://digitalcommons.unl.edu/nebgamestaff

Part of the Environmental Sciences Commons

Witt, Larry A. and Sisson, Leonard H., "Beggar-Tick Injury to a Northern Cricket Frog and Two Species of Minnows" (1969). Nebraska Game and Parks Commission -- Staff Research Publications. 32. https://digitalcommons.unl.edu/nebgamestaff/32

This Article is brought to you for free and open access by the Nebraska Game and Parks Commission at DigitalCommons@University of Nebraska - Lincoln. It has been accepted for inclusion in Nebraska Game and Parks Commission -- Staff Research Publications by an authorized administrator of DigitalCommons@University of Nebraska - Lincoln. 


\title{
Short Notes
}

\section{Beggar-Tick Injury to a Northern Cricket Frog and Two Species of Minnows ${ }^{1}$}

\author{
LARRY A. WITT and LEONARD H. SISSON \\ Nebraska Game and Parks Commission, Lincoln, Nebraska 68509
}

Various authors have reported on injury to small fishes by achenes of beggar-ticks (Bidens sp.) Reimers and Bond (1966) reported on injury by beggar-ticks to redside shiners, Richardsonius balteatus and young chinook salmon Oncorbynchus tshawytscha. They suggested that presence of beggar-tick plants along banks of hatchery ponds and raceways might be injurious to young of the most aggressive feeders among fish. Allison (1967) described mortality of fingerling coho salmon, Oncorbyncbus kisutch, caused by beggar-tick, B. cernuus, achenes. He noted losses of coho salmon 51 to $90 \mathrm{~mm}$ in total length held in hatchery raceways. Dead and dying fish had beggar-tich achenes imbedded in gill arches and oral cavities which had resulted in fungus infections.

Injury by achenes of beggar-tick, Bidens cernua, to three cyprinids and one frog was noted during collection of fishes in southeastern Nebraska in fall, 1967. On October 26, a sand shiner, Notropis stramineus, $47 \mathrm{~mm}$ in total length, was collected by seine from the Big Nemaha River, Richardson County, Nebraska. Barbed awns of a beggartick achene were firmly imbedded in the tissue covering the left maxilla and the lower portion of the left orbit (Figure 1). Inflammation was lacking in the area of attachment and the specimen appeared to be in good health. Beggar-tick plants were not observed in the sample area.

A similar situation was noted on November 1 , when two of nine creek chubs, Semotilus atromaculatus, collected by seine at the confluence of Whiskey Run and the Little Nemaha River, Nemaha County, Nebraska, had beggar-tick achenes imbedded in their snouts and oral cavities. These fish were 35 and $36 \mathrm{~mm}$ in total length. Each fish had a single achene protruding anteriorly from its snout. Seemingly, the one specimen was unaffected by the attached achene, however, the right eye and snout of the other creek chub were inflamed. Position of attachmen of achenes suggests attempted ingestion by the minnows.

Transactions of the Kansas Academy of Science, Vol. 72, No. 2, 1969. Published September 17, 1969.

${ }^{1}$ A contribution of Federal Aid in Fish Restoration, Project F-4-R, Nebraska. 
Also, beggar-ticks were imbedded in one of three northern cricket frogs, Acris crepitans, captured on the river bank near the latter seining operation. Nine achenes were imbedded in the right hind foot, and one in the nictitating membrane and tissue surrounding the left eye (Figure

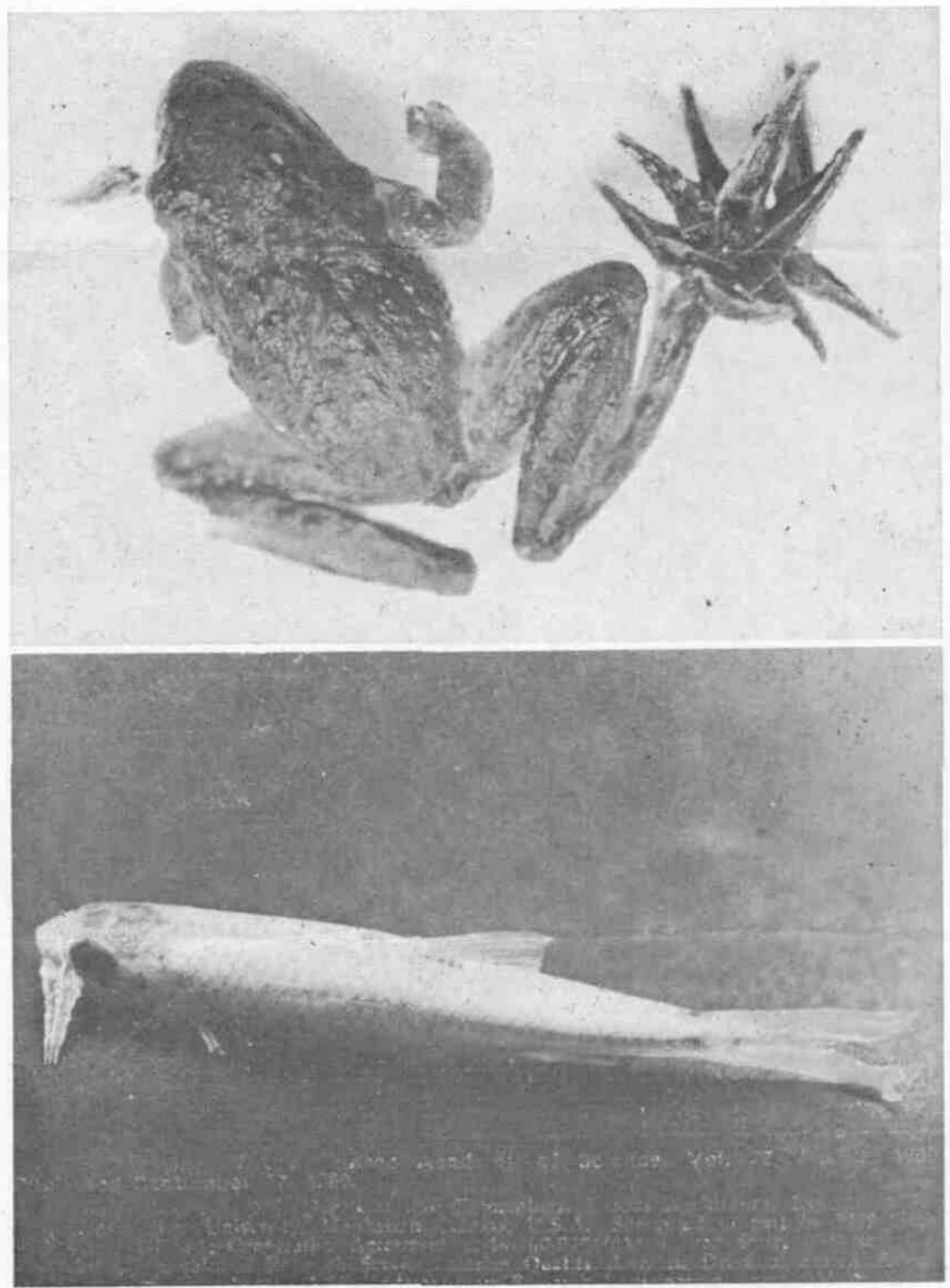

Figure 1. Northern cricket frog, showing Bidens cernuus achenes imbedded in the left orbit and right foot, and a sand shiner showing the barbed awns of an achene imbedded in the tissue covering the left maxilla the lower portion of the left orbit. 
1). These obviously hindered normal movement of the frog. Beggartick plants were common on stream banks adjacent to seining operations. It is suggested that continued attachment of beggar-tick achenes could have caused death of the frog and fishes by restricting their feeding, by increasing their vulnerability to predation, or by infection.

\section{Literature Cited}

Alusson, L. N. 1967. Beggar-ticks cause mortality among fingerling coho salmon. Progressive Fish-Culturist, 29(2):113 p.

Rrimers, P. E. and C. E. Bond. 1966. Occurrence of the Bidens (sp.) achene in the snout of chinook salmon and redside shiners. Progressive FishCulturist, 28(1):62 p. 